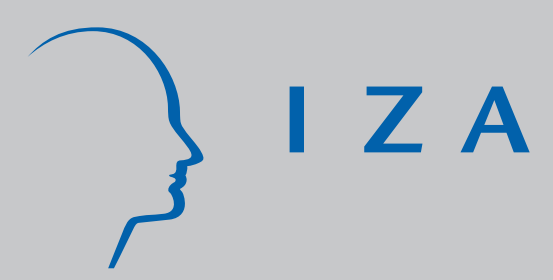

IZA DP No. 5876

Severance Pay Mandates: Firing Costs, Hiring Costs, and Firm Avoidance Behaviors

Donald O. Parsons

July 2011 


\title{
Severance Pay Mandates: Firing Costs, Hiring Costs, and Firm Avoidance Behaviors
}

\author{
Donald O. Parsons \\ George Washington University \\ and IZA
}
Discussion Paper No. 5876
July 2011

IZA

P.O. Box 7240

53072 Bonn

Germany

Phone: +49-228-3894-0

Fax: +49-228-3894-180

E-mail: iza@iza.org

Any opinions expressed here are those of the author(s) and not those of IZA. Research published in this series may include views on policy, but the institute itself takes no institutional policy positions.

The Institute for the Study of Labor (IZA) in Bonn is a local and virtual international research center and a place of communication between science, politics and business. IZA is an independent nonprofit organization supported by Deutsche Post Foundation. The center is associated with the University of Bonn and offers a stimulating research environment through its international network, workshops and conferences, data service, project support, research visits and doctoral program. IZA engages in (i) original and internationally competitive research in all fields of labor economics, (ii) development of policy concepts, and (iii) dissemination of research results and concepts to the interested public.

IZA Discussion Papers often represent preliminary work and are circulated to encourage discussion. Citation of such a paper should account for its provisional character. A revised version may be available directly from the author. 


\begin{abstract}
Severance Pay Mandates: Firing Costs, Hiring Costs, and Firm Avoidance Behaviors*

The potentially adverse labor market effects of severance pay mandates are a continuing source of policy concern. In a seminal study, Lazear (1990) found that contract avoidance of severance pay firing costs was theoretically simple - a bonding scheme would do - but that empirically the labor market distortions were large. Subsequent empirical work resolved the apparent paradox - firing cost effects are modest even without firm avoidance activities. To explore why that should be so, formal measures of severance-induced firing costs and hiring costs are derived. Firing costs are, it turns out, systematically less than benefit generosity alone would imply. Moreover their interrelationship with hiring costs, often employed in empirical studies as a substitute measure, is complex, with co-movements varying in sign and magnitude across policy parameters and the economic environment. Although the analysis assumes a fixed benefit mandate, the cost measures are easily extended to assess the impact of service-linked severance benefits on age-specific employment levels. The model permits design of a cohort-neutral severance mandate - which is not a flat rate structure.
\end{abstract}

JEL Classification: J65, J41, J33

Keywords: $\quad$ severance pay, firing costs, hiring costs, layoff, employment, insurance, savings, moral hazard

Corresponding author:

Donald O. Parsons

Economics Department

George Washington University

2115 G Street NW, Monroe Hall 368

Washington, DC 20052

USA

E-mail: dopars@gwu.edu

\footnotetext{
* This work was stimulated by presentations and discussions at the World Bank/IIASA/Ludwig Boltzmann Institute International Workshop on Severance Pay Reform: Toward Unemployment Savings and Retirement Accounts, Laxenberg/Vienna, November 7-8, 2003. The luxury of a sabbatical year (2008-2009) at GW was especially helpful in its development. Detailed comments by Timothy Perri are gratefully acknowledged.
} 


\section{Introduction}

The potentially large deadweight losses of mandated severance plans have been a source of concern since the 1980s, when high unemployment rates lingered in Europe relative to the U.S. ${ }^{1}$ Intense investigation of severance pay effects followed, stimulated in part by the strong, adverse link between severance pay benefits and labor market performance (lower employment and higher unemployment) reported in Lazear (1990). ${ }^{2}$ Somewhat paradoxically, Lazear demonstrated in the same paper that severance mandates could be undone through a simple bonding scheme. Lazear reconciled his theory and empirical results with an appeal to widespread worker credit constraints, which would make bonding costly.

Subsequent theoretical work deepened the mystery. Lazear proposed to undo the severance mandate by paying out equivalent benefits to all workers in each period, whether employed or separated (for any reason). One can also contractually neutralize severance (insurance) induced firing costs by converting the plan into a severance savings plan, essentially offering benefits for all separations, including retirement, not simply involuntary layoffs, Parsons (2011a). Not only are severance savings plans a more familiar mechanism, essentially pensions, they have systematically lower expected costs to the firm at the time of hire.

The apparent paradox has been resolved by subsequent empirical work, which suggests that severance insurance mandates (at current levels of benefits and enforcement) do not substantially distort layoffs or employment. ${ }^{3}$ Contractual avoidance of firing cost distortions is unnecessary. Widespread voluntary severance insurance plans in the U.S., often as generous as those mandated in OECD countries, perhaps makes this finding

\footnotetext{
${ }^{1}$ Blanchard (2006) provides a review of European unemployment concerns over the last several decades, highlighting his own important contributions. See also Boeri and Garibaldi (2009). For general discussions of severance pay issues, see Emerson (1988), Lazear (1990), Buechtemann (1992). OECD (1999, 2004, 2006), and Heckman and Pagés (2004), and Holzmann, Pouget, Weber, and Vodopivec (2011).

${ }^{2}$ Vodopivec (2004) provides an introduction to the returns as well as the costs of insuring against job displacement.

${ }^{3}$ See Blau and Kahn (1999) and Boeri, Helppie, and Macis (2008) for reviews of employment protection effects, while Parsons (2011b) focuses on severance plan effects.
} 
unsurprising, Bishow and Parsons (2004) and Parsons (2005). However the absence of serious effects raises a quite different question, one that is the focus of the present paper-why are distortions so small? A formal model of the firm's employment decision is developed and explicit measures of severance-induced firing costs and hiring costs derived that shed light on this question.

The explicit firing cost measure formalizes the intuitive argument that firing costs are systematically less than benefit generosity because present payouts typically reduce future liabilities, Parsons (2011a). Severance savings plan, for example, have no firing cost implications because benefit payouts induce an equal and opposite reduction in future liabilities. ${ }^{4}$ Similarly severance insurance benefits reduce future liabilities to the extent the firm can expect to pay out benefits (or engage in costly avoidance activities) in the future if the worker is retained.

Converting a severance insurance plan into a severance savings plan with zero firing costs requires only that the firm pay out the same separation benefits for all separations, not only involuntary separations (layoffs). In the spirit of Lazear, though, this undoing does not leave hiring costs unaffected. Gross hiring costs increase with the coverage of more separation events even as expected firing costs fall (the probability of future payouts conditional on retention rises). The labor market impact of severance pay mandates depends on both firing costs and hiring costs and the linkage between them. The "firing cost" literature is oddly casual in the empirical implementation of the concept; many studies simply include severance pay measures, a reduced form approach that does not distinguish between firing cost and hiring cost measures. ${ }^{5}$ More recent studies focus on hiring cost measures of severance mandates, although often maintaining the firing cost jargon ${ }^{6}$

\footnotetext{
${ }^{4}$ The firm may have an economic stake in when it pays its liabilities if interest accrues at nonmarket rates, Garibaldi and Pacelli (2003). See also Ferrer and Riddell (2011)'s discussion of Brazil.

${ }^{5}$ See Parsons (2011b) for a detailed discussion of the severance mandate literature.

${ }^{6}$ Heckman and Pagés (2004), however, proposed a hiring cost measure for inclusion in their employment and unemployment equations in the spirit of the gross hiring cost measure that emerges here, while alerting the reader to the neglect of firing cost measures.
} 
The novelty of the present paper is its focus on precise measurement of the firing cost and hiring cost concepts. The formal model is in the spirit of Gavin's unpublished 1986 paper, major elements of which were reviewed by Emerson (1988), but is closer in structure to the less general model of firm employment decisions found in Pagés and Montenegro (2007). ${ }^{7}$ The focus of their analysis was the redistributive effects of mandated benefits increasing in job tenure. The flat rate benefit model developed below extends easily to this case (see Section VIII below), permitting the design of a cohort neutral severance mandate.

The paper proceeds in the following way. I first review severance pay structures and two avoidance mechanisms-(i) layoff reduction and (ii) contract conversion (to a savings plan). The first avoids the full impact of firing costs through inefficient worker retention, the second avoids firing costs altogether, though perhaps at the expense of increased hiring costs. In Section III a three-period stochastic contracting model is developed that permits exploration of these options. As a benchmark, firm behavior in the absence of severance pay is examined in Section IV. The impact of a severance mandate on the firm's layoff/employment decisions in the absence of contractual avoidance activities is then derived in Section $\mathrm{V}$, while optimal behavior with contractual avoidance strategies is considered in Section VI. The richness and complexity of the firing cost/hiring cost interface are illustrated in Section VII. Section VIII extends the fixed benefit plan to one with mandated benefits that increase with service (as most do), an issue raised by Pagés and Montenegro (2007), with some unexpected results. Section IX concludes.

\section{Severance Pay Mandates and Firm Avoidance Behaviors: Background}

Firing costs potentially arise whenever firms self-finance involuntary separation insurance; the firm may choose to keep a worker on the payroll who is paid more than her productivity warrants in order to avoid the severance payout ("layoff avoidance"). ${ }^{8}$

\footnotetext{
7 Nickell (1978) and Bertola (1992) provide clear introductions to the underlying employment dynamics in a world of certainty. Bentolila and Bertola (1990) and Bertola (1990) introduce uncertainty. Bertola (1999) provides a review, Blanchard (1998) an accessible discussion.

${ }^{8}$ Of course commercial insurers have the same immediate incentive to avoid payment of claims, but presumably face stronger market forces to pay appropriate claims. See Parsons (2011c) for a more complete discussion of this issue.
} 
Alternatively the employer may choose to redesign the employment contract in a way that reduces or eliminates firing costs ("contract avoidance").

In the absence of information and incentive problems, contract avoidance techniques exist, perhaps most obviously through reinsuring the risk. Firms, especially smaller firms, typically reinsure benefit risks when they can, for example health insurance and life insurance. This may not be especially easy in the case of involuntary separation insurance. Insuring against one's own actions, much like life insurance for suicide, has obvious, if not insurmountable, problems that increase reinsurance costs. ${ }^{9}$

In this case the firm's private information is its insider knowledge of its own demand and cost conditions. Unlike temporary separation risk, which can be monitored cheaply through experience rating of claims behavior, permanent separations are often precipitated by large demand shocks and by plant closings, perhaps unique in the firm's experience. Stock markets appear to be "surprised" by firm plant-closing announcements, and one could expect that workers and insurers are as well. ${ }^{10}$ If firing costs are heavy and reinsurance prohibitively costly, the employer may find it profitable to contract around the mandate in other ways. Lazear (1990) famously proposed a benefit/bonding scheme; the firing costs of a severance insurance mandate can be eliminated if the firm offers the worker each period the same payment whether she remains employed or is separated. This payout to the employed could be executed through a wage premium, though a retention bonus would work equally well. If workers have reasonable access to capital and the firm faces no institutional limits on employment payout policies, the firm can recapture the cost of this additional generosity in the same way it recaptures the cost of the severance payment itself, through an upfront bond.

The firm need not pay out benefits to the employed as well as the separated to avoid firing costs, it need only pay out the same benefits to all workers sometime, for example for

\footnotetext{
${ }^{9}$ Suicide is often covered by life insurance plans, but with a delay, often two years, in benefit eligibility.

${ }^{10}$ For empirical evidence of stock price effects of plant closing announcements, see Blackwell, Marr, and Spivey (1990), Gombola and Tsetsekos (1992), and Clinebell and Clinebell (1994).
} 
all types of separations, essentially converting the plan into a severance savings plan, which has no firing cost implications if benefits accrue with interest. The benefit would be paid for example at retirement as well as following voluntary separation. Framing the plan in this way reveals that severance insurance plans function much like savings plans in some circumstances, with a similar implication of zero firing costs if for example workers have no likelihood of lifetime employment. In assessing a severance plan, it is important to know (i) the precise turnover eligibility requirements for receiving severance insurance payouts, and (ii) the distribution of separation probabilities by type-layoff, discharge, quit, incapacity, or retirement. $^{11}$

The distinction between severance insurance plans and severance savings plans will be critical in the discussion to follow. ${ }^{12}$ Severance savings plans are equivalent to defined contribution pension plans as characterizes by $401(\mathrm{k})$ plans in the U.S. (though with no penalty for withdrawal at job separation prior to retirement). They would be distinguished from unemployment insurance savings accounts-Topel (1990) and Feldstein and Altman (2007) —only in that all accumulated assets are disbursed at the time of separation without regard to unemployment experience. The insurance/savings distinction is used below to develop more general measurement models of the firing cost and hiring cost implications of severance mandates.

\section{The Basic Contracting Model ${ }^{13}$}

Consider a contracting model with three potential employment periods-an initial hiring/work period (1) followed by two potential work/layoff periods ( 2 and 3 ). These are followed by a retirement period (4) that will be ignored for now, but see Section VI when we return to the savings plan option. Firms have a positive per period discount factor, constant across periods $\delta, 0<\delta \leq 1$

\footnotetext{
${ }^{11}$ A review of worker turnover concepts can be found in Parsons (1977).

12 I use generic labels in this study. Heckman and Pagés (2004) employ the labels "indemnity for dismissal" and "seniority pay" to distinguish severance insurance from severance savings.

${ }_{13}$ Parsons (1986), Malcomson (1999), and Salanié (2005) provide general reviews of the contracting literature. Again the basic model is similar to that of Pagés and Montenegro (2007).
} 
Demand uncertainty is indexed by productivity, which is either high or low. Denote worker productivity by $V_{i}$, i=H,L, where:

$$
V_{H}>V_{L}
$$

and the corresponding probabilities by $\theta_{\mathrm{i}}, \mathrm{i}=\mathrm{H}, \mathrm{L}$ :

$$
\theta_{H}, \theta_{L}>0, \text { and } \theta_{H}+\theta_{L}=1
$$

Assume further that the demand draws are independent across periods, although the discussion considers alternatives.

We will assume that hiring occurs in the high demand period only, and that the firm incurs fixed recruiting and training costs $\left(h_{0}, h_{0}>0\right)$. Sufficient recruiting and training costs will insure lifetime (three period) contracts, though not necessarily under all demand conditions. Wages are assumed fixed over the contract life at the time of hire. ${ }^{14}$ Under reasonable conditions, competition in the labor market insures that ${ }^{15}$

$$
V_{H}-w>0 \quad \text { and } V_{L}-w<0 .
$$

Voluntary separations (quits) are exogenous and occur at a constant rate $\alpha, 0<\alpha<$ 1 , at the beginning of periods (2) and (3), after which the firm makes additional layoffs as required. All layoffs are permanent; rehires do not occur. Layoffs will not typically occur in the high demand state in this model (see however Section VIII, which considers benefits increasing in service) and the discussion focuses on layoff decisions in the second and third periods in the low demand state only.

\section{No Severance Pay}

Consider first the firm's decision-making in the absence of a severance mandate. Solving the model by backward induction:

\section{Period 3 (Layoff Period 2)}

The firm will release the worker at the beginning of period 3 if the low demand state is realized because:

14 Contractual wage rigidity was a primary focus of the early employment contracting literature, Baily (1977), Azariadis (1975), and Rosen (1985).

15 The variation in demand across states must exceed training and recruiting costs. Timothy Perri provided me with a formal proof of this assertion, which is available upon request. 


$$
V_{L}-w<0 .^{16}
$$

With this layoff decision rule, expected profits at the beginning of period 3 are:

$$
E \Pi_{3}=(1-\alpha) \theta_{H}\left(V_{H}-w\right)>0
$$

\section{Period 2 (Layoff Period 1)}

The firm will lay off workers in period 2 in the low demand state if:

$$
\begin{aligned}
& \left(V_{L}-w\right)+\delta E \Pi_{3}<0, \text { or } \\
& \left(V_{L}-w\right)+\delta(1-\alpha) \theta_{H}\left(V_{H}-w\right)<0,
\end{aligned}
$$

where $\delta(1-\alpha) \theta_{H}\left(V_{H}-w\right)>0$. The layoff algorithm for cohort 2 (younger) workers is more forgiving (productivity in the low demand state must be lower to induce layoff) than for older workers, and for intuitive reasons. The firm anticipates the possibility of future profits if the worker is retained from the fresh demand draw at the beginning of period $3 .^{17}$

Note 1: In the absence of severance pay, the range of conditions under which cohort 2 workers will be laid off is less than the range of conditions under which cohort 3 workers will be laid off as long as demand conditions are not perfectly correlated between periods 2 and 3 .

Because we have a special interest in layoff distortions, assume that, in the absence of severance benefits, layoffs will occur in the low demand state in period 2 and a

fortiori in period 3. Expected profits entering period 2 are then:

$$
\begin{aligned}
E \Pi_{2} & =(1-\alpha) \theta_{\mathrm{H}}\left\{\left(\mathrm{V}_{\mathrm{H}}-\mathrm{w}\right)+\delta \mathrm{E} \Pi_{3}\right\} \\
& =(1-\alpha) \theta_{\mathrm{H}}\left(\mathrm{V}_{\mathrm{H}}-\mathrm{w}\right)+\delta\left\{(1-\alpha) \theta_{\mathrm{H}}\right\}^{2}\left(V_{H}-w\right) \\
& =\left\{(1-\alpha) \theta_{\mathrm{H}}+\delta\left\{(1-\alpha) \theta_{\mathrm{H}}\right\}^{2}\right\}\left(V_{H}-w\right)
\end{aligned}
$$

\section{Period 1 (The Hiring Period)}

The firm will hire workers only if expected profits are nonnegative, which is presumably the high demand state. Assuming again some fixed cost of recruiting and training $\left(h_{0}\right)$, then hiring will occur if:

$$
\begin{aligned}
E \Pi_{1} & =\left(\mathrm{V}_{\mathrm{H}}-\mathrm{w}\right)+\delta E \Pi_{2}-\mathrm{h}_{0} \geq 0 \\
& =\left[1+\delta(1-\alpha) \theta_{\mathrm{H}}+\left\{\delta(1-\alpha) \theta_{\mathrm{H}}\right\}^{2}\right]\left(V_{H}-w\right)-\mathrm{h}_{0} \geq 0
\end{aligned}
$$

\footnotetext{
${ }^{16}$ Equivalently expected profits under retention are less than expected profits under layoff.

17 If the low demand state in period 2 is "permanent," that is carries over to period 3 , and the second period layoff criterion is identical to the final period rule: $V_{L}-w<0$
} 
Competition among firms will drive up wages until expected profits are zero (the "competitive wage"), namely:

$$
\widetilde{w}=V_{H}-\frac{h_{0}}{1+\delta(1-\alpha) \theta_{\mathrm{H}}+\left\{\delta(1-\alpha) \theta_{\mathrm{H}}\right\}^{2}}
$$

Productivity in the high demand state exceeds wages by the amortized recruiting and training costs. Amortization in this case refers to the discounted sum of expected lifetime employment (high demand) periods.

\section{Severance Insurance Mandate: No Contract "Undoing"}

Consider now the impact of a severance insurance mandate that requires the firm to pay severance $\boldsymbol{B}$ if the worker is laid off, nothing otherwise-in an economy in which the mandate is not contractually undone. Much depends on whether the benefit mandate is sufficient to induce layoff avoidance or not. Consider each possibility in turn.

\section{A. No layoff avoidance}

If the mandated benefit is less than some critical level, it will induce no change in firm layoff behavior. Proceeding by backward induction in this circumstance:

\section{Period 3 (Layoff Period 2)}

The firm will of course retain the worker in the good state. The firm will lay off the worker in period 3 if net productivity (productivity less wages) in the low demand state falls below the mandated severance benefit: ${ }^{18}$

$$
V_{L}-w<-B
$$

In this period, then, severance-induced firing costs are precisely equal to mandated benefits

$$
F C_{3}(B)=B
$$

If the firm does not release the worker in this period, future severance liabilities are zero (the worker proceeds to normal, uncovered retirement). Entering the period, expected profits in period 3 are:

$$
E \Pi_{3}=(1-\alpha)\left\{\theta_{H}\left(V_{H}-w\right)-\theta_{L} B\right\}
$$

\footnotetext{
${ }^{18}$ Again this intuitive condition follows from expected profits under retention being less than expected profits under layoff.
} 


\section{Period 2 (Layoff Period 1)}

The firm will lay off workers in period 2 in the low demand state if:

$$
\begin{aligned}
& \left(V_{L}-w\right)+\delta E \Pi_{3}<-B, \text { or } \\
& \left(V_{L}-w\right)+\delta(1-\alpha)\left\{\theta_{H}\left(V_{H}-w\right)-\theta_{L} B\right\}<-B
\end{aligned}
$$

Rearranging terms:

$$
\left(V_{L}-w\right)+\delta(1-\alpha) \theta_{H}\left(V_{H}-w\right)<-B+\delta(1-\alpha) \theta_{L} B .
$$

The left hand side of this inequality is unchanged from the no severance case, Equation (3), the (negative) low demand productivity net of wages plus the (positive) discounted probability of a better demand state in period 3.

Second period firing costs, the negative of the right hand side, are however reduced in expectation, and no longer equal the mandated severance benefit $(B)$.

$$
F C_{2}(B)=B-\delta(1-\alpha) \theta_{L} B=\left\{1-\delta(1-\alpha) \theta_{L}\right\} B .
$$

The expected severance costs incurred by a layoff in the second period are not the mandated severance payment, but that payment adjusted to reflect the reduced likelihood the firm will have to pay out severance in the next period. Firing costs are zero, for example, if the likelihood of layoff (and benefit payout) in the next period is one, the discount factor is one and there is no natural (uncovered) attrition, $(\alpha=0)$. Conversely firing costs will approach severance benefits if the likelihood of layoff in the next period approaches zero or the discount factor approaches zero or the natural attrition rate approaches one.

We will expand on the comparative statics below (Section VII), but for now note that the expected third period severance liability in the absence of a second period layoff is greater the larger the probability of a low demand state $\theta_{L}$ in the next period. Severance payouts might only be postponed. Conversely firing costs rise with the rise in the voluntary attrition rate $\alpha$, which reduces the likelihood of future severance payouts if retained today.

Summarizing:

Proposition 1: Firing costs for cohort 2 workers are systematically less than severance benefits unless there is zero voluntary attrition and the probability of layoff in the next period is one and the discount factor is one. 
If layoffs still occur in the second (and third) period in the low productivity state, expected profits entering period 2 are:

$$
\begin{aligned}
E \Pi_{2} & =(1-\alpha)\left[\theta_{\mathrm{H}}\left\{\left(\mathrm{V}_{\mathrm{H}}-\mathrm{w}\right)+\delta \mathrm{E} \Pi_{3}\right\}-\theta_{\mathrm{L}} \mathrm{B}\right] \\
& \left.=(1-\alpha) \theta_{\mathrm{H}}+\delta\left\{(1-\alpha) \theta_{\mathrm{H}}\right\}^{2}\right]\left(V_{H}-w\right)-(1-\alpha)\left\{1+\delta(1-\alpha) \theta_{H}\right\} \theta_{L} B .
\end{aligned}
$$

Ceteris paribus, expected profits are reduced by the severance mandate to the extent the worker collects the severance upon departure from the firm, which would not occur if the worker (i) leaves voluntarily (quits) or (ii) attains "normal" retirement age (is not laid off in period 2 or 3$)$.

\section{Period 1 (The Hiring Period)}

The firm will hire workers only if expected profits are nonnegative, presumably in the first period high demand state only. With positive fixed recruitment and training costs $\left(h_{0}\right)$ :

$$
E \Pi_{1}=\left(\mathrm{V}_{\mathrm{H}}-\mathrm{w}\right)+\delta \mathrm{E} \Pi_{2}-\mathrm{h}_{0} \geq 0
$$

In this case (no change in layoff behavior), expected profits over the contract life to the firm are:

$$
\begin{aligned}
E \Pi_{1} & =\left(\mathrm{V}_{\mathrm{H}}-\mathrm{w}\right)+\delta E \Pi_{2}-\mathrm{h}_{0} \\
& =\left[1+\delta(1-\alpha) \theta_{\mathrm{H}}+\left\{\delta(1-\alpha) \theta_{\mathrm{H}}\right\}^{2}\right]\left(V_{H}-w\right)-\mathrm{h}(\mathrm{B})-\mathrm{h}_{0}
\end{aligned}
$$

where the severance induced expected gross hiring costs $(h(B))$ are:

$$
h(B)=\left[\delta(1-\alpha) \theta_{\mathrm{L}}+\{\delta(1-\alpha)\}^{2} \theta_{\mathrm{H}} \theta_{\mathrm{L}}\right] \mathrm{B}
$$

This reflects the expected severance expenditures under the program and is essentially the Heckman and Pagés (2004) model. From Equation (15) one can derive:

Proposition 2: The hiring costs associated with severance benefit mandates increase with the discount factor and the likelihood of layoff and decrease with the likelihood of voluntary (uninsured) attrition.

Presumably competition would force up the "competitive wage" to the zero expected profit point, or:

$$
\widetilde{w}=V_{H}-\frac{h_{0}+h(B)}{1+\delta(1-\alpha) \theta_{\mathrm{H}}+\left\{\delta(1-\alpha) \theta_{\mathrm{H}}\right\}^{2}}
$$


Productivity in the high demand state must exceed wages by the amortized cost of recruitment costs and expected severance related hiring costs. ${ }^{19}$

\section{B. Layoff avoidance}

If mandated benefits are sufficiently large (relative to the low demand productivity), they will induce layoff avoidance--the firm will retain workers on the payroll in the low demand state. By backward induction:

\section{Period 3 (Layoff Period 2)}

The layoff algorithm is the same as above. If benefits are sufficiently large, the layoff condition will not be met and the firm will optimally retain workers in the low demand state:

$$
V_{L}-w \geq-B
$$

in which case expected third period profits become:

$$
E \Pi_{3}=(1-\alpha)\left\{\theta_{H}\left(V_{H}-w\right)+\theta_{L}\left(V_{L}-w\right)\right\}
$$

Expected profits must be higher than those in Equation (9), or the firm would simply lay the worker off.

\section{Period 2 (Layoff Period 1)}

As earlier the layoff decision rule in period 2 is defined by the net cost of retaining the worker relative to releasing her, so that the firm will retain the worker in the low demand state if:

$$
\left(V_{L}-w\right)+\delta E \Pi_{3} \geq-\mathrm{B}, \text { or }
$$

If this holds, then retention in the third period holds as well, and the expected value of period 3 profits is now defined by Equation (17), not by Equation (10), so:

$$
\begin{aligned}
& \left(V_{L}-w\right)+\delta(1-\alpha)\left\{\theta_{H}\left(V_{H}-w\right)+\theta_{L}\left(V_{L}-w\right)\right\} \geq-\mathrm{B}, \text { or } \\
& \left.\left(V_{L}-w\right)+\delta(1-\alpha) \theta_{H}\left(V_{H}-w\right) \geq-\mathrm{B}-\delta(1-\alpha) \theta_{L}\left(V_{L}-w\right)\right\} .
\end{aligned}
$$

Recall that $\left(V_{L}-w\right)<0$. Knowing that it will retain the worker in the third period, second period firing costs become:

$$
\left.F C_{2}=\mathrm{B}+\delta(1-\alpha) \theta_{L}\left(V_{L}-w\right)\right\}
$$

19 Recall that the labor demand curve is perfectly elastic, so that the workers preferences over severance benefits affect equilibrium employment but not total compensation. Mandated (expected) expenditures on severance benefits force down wages dollar for dollar in this model. See below, Section VIII. 
Note that second period firing costs will be higher if the firm is expected to retain the worker in the low demand state in the next period than if it expects to lay them off (Equation 9a): The "adjustment" factor is larger (less negative) if retention implies higher profits:

$$
\left.\delta(1-\alpha) \theta_{L}\left(V_{L}-w\right)\right\}>\delta(1-\alpha) \theta_{L} B
$$

A layoff now means a lesser reduction in future severance liabilities.

Proposition 3: If it is optimal to retain cohort 3 workers in the low demand state, potential firing costs for the period 2 cohort is higher--the reduction in future severance liabilities is less-and the likelihood of layoff in period 2 drops.

With retention in both years, expected profits on the contract entering period 2 are:

$$
\begin{aligned}
E \Pi_{2} & =(1-\alpha)\left[\theta_{\mathrm{H}}\left(\mathrm{V}_{\mathrm{H}}-\mathrm{w}\right)+\theta_{\mathrm{L}}\left(\mathrm{V}_{\mathrm{L}}-\mathrm{w}\right)+\delta \mathrm{E} \Pi_{3}\right] \\
& =(1-\alpha)\left[1+\delta(1-\alpha)\left\{\theta_{\mathrm{H}}\left(\mathrm{V}_{\mathrm{H}}-\mathrm{w}\right)+\theta_{\mathrm{L}}\left(\mathrm{V}_{\mathrm{L}}-\mathrm{w}\right)\right\}\right.
\end{aligned}
$$

Ceteris paribus, expected profits are (i) increased relative to the alternative regime in which the workers were laid off, but (ii) reduced relative to the zero mandate regime, because the firm is induced to retain a worker on the payroll who would in the absence of the mandate be laid off.

\section{Period 1 (The Hiring Period)}

Again the firm will hire workers only if expected profits are nonnegative. With positive fixed recruitment and training costs $\left(h_{0}\right)$ :

$$
\begin{aligned}
E \Pi_{1}= & \left(\mathrm{V}_{\mathrm{H}}-\mathrm{w}\right)+\delta \mathrm{E} \Pi_{2}-\mathrm{h}_{0} \\
= & {\left[1+\delta(1-\alpha) \theta_{\mathrm{H}}+\left\{\delta(1-\alpha) \theta_{\mathrm{H}}\right\}^{2}\right]\left(V_{H}-w\right) } \\
& \quad+\left[\delta(1-\alpha) \theta_{\mathrm{L}}+\{\delta(1-\alpha)\}^{2} \theta_{\mathrm{H}} \theta_{\mathrm{L}}\right]\left(\mathrm{V}_{\mathrm{L}}-\mathrm{w}\right)-\mathrm{h}_{0} \\
& \quad\left[1+\delta(1-\alpha) \theta_{\mathrm{H}}+\left\{\delta(1-\alpha) \theta_{\mathrm{H}}\right\}^{2}\right]\left(V_{H}-w\right)-\mathrm{h}(\mathrm{B})-\mathrm{h}_{0}
\end{aligned}
$$

where the severance-induced expected gross hiring costs $(\mathrm{h}(\mathrm{B}))$ are:

$$
h(B)=\left[\delta(1-\alpha) \theta_{\mathrm{L}}+\{\delta(1-\alpha)\}^{2} \theta_{\mathrm{H}} \theta_{\mathrm{L}}\right]\left(\mathrm{V}_{\mathrm{L}}-\mathrm{w}\right) .
$$

The severance-induced hiring costs are the costs of "carrying" workers in the low demand states when the firm would otherwise lay them off minus the expected gain in period three if high demand returns. At sufficiently high severance benefits, the firm retains workers in the low demand state and avoids benefit payouts entirely; further increases in benefit mandates 
generate no additional distortions. Although an obvious implication of the fact that expected profits are higher if retention in the low demand state is profit maximizing, for completeness:

Proposition 4: If it is optimal to retain cohort 2 and/or 3 workers in the low demand state, hiring costs will be lower than if the workers were released and severance paid.

Presumably competition would force up the "competitive wage" to the zero expected profit point, or:

$$
\widetilde{W}=\frac{A}{A+C} V_{H}+\frac{C}{A+C} V_{L}-\frac{h_{0}}{A+C}
$$

where $A \equiv 1+\delta(1-\alpha) \theta_{\mathrm{H}}+\left\{\delta(1-\alpha) \theta_{\mathrm{H}}\right\}^{2}$ and $C \equiv \delta(1-\alpha) \theta_{\mathrm{L}}+\{\delta(1-\alpha)\}^{2} \theta_{\mathrm{H}} \theta_{\mathrm{L}}$.

\section{A Severance Mandate with Contractual Avoidance (Severance Savings)}

The firm is made worse off by the severance (insurance) mandate, at least in the short run, though its losses might be limited by strategic reductions in layoffs in the low demand state, particularly in the second period. That said, the firm may do better by converting the insurance mandate into a savings plan by offering a supplementary benefit package.

Consider the impact on firing costs and hiring costs of a promise by the firm to pay the worker B if the worker leaves voluntarily or at retirement as well as at layoff. Because the firm will now be offering retirement benefits (to those who remain with the firm throughout their work lives, the fourth $\left(4^{\text {th }}\right)$ period must be considered. For simplicity, consider the case with no layoff avoidance and proceed by backward induction.

\section{Period 4 (Retirement)}

Assume all workers pass into retirement following period $3 .^{20}$ Entering the retirement period, expected profits in period 4 are now:

$$
E \Pi_{4}=-\mathrm{B}
$$

\section{Period 3 (Layoff period 2)}

As before the firm will lay off the worker in the low demand state in period 3 if net expected profits conditional on layoff are higher than if the worker is retained:

${ }^{20}$ As everywhere above, mortality risk is ignored here. 


$$
\begin{array}{r}
\left(V_{L}-w\right)+\delta E \Pi_{4}<-B \\
\left(V_{L}-w\right)<-(1-\delta) B \text { so } \\
F C_{3}(B)=(1-\delta) B
\end{array}
$$

Note EQ25: If $\delta=1$, firing costs in period 3 are zero and the layoff rule reduces to the "no severance" rule, Equation (1). More generally firing costs are zero in the savings model if the severance promise accrues interest between periods, so that $B_{t+1}=$ $\frac{1}{\delta} B_{t}$, for $t=2$ and 3 .

If workers are laid off in the low demand state in period 3, expected profits at the beginning of period 3 are:

$$
\begin{aligned}
E \Pi_{3} & =\alpha(-B)+(1-\alpha)\left[\theta_{H}\left\{\left(V_{H}-w\right)+\delta E \Pi_{4}\right\}+\theta_{L}(-B)\right] \\
& =(1-\alpha) \theta_{H}\left(V_{H}-w\right)-\left[\alpha+(1-\alpha)\left\{\delta \theta_{H}+\theta_{L}\right\}\right] B
\end{aligned}
$$

Note EQ26: again: if $\delta=1$, the coefficient on the second term in Equation (19), namely $-\left[\alpha+(1-\alpha)\left\{\delta \theta_{H}+\theta_{L}\right\}\right]$, reduces to -1 .

\section{Period 2 (Layoff Period 1)}

The firm will lay off workers in period 2 in the low demand state if:

$$
\begin{aligned}
& \left(V_{L}-w\right)+\delta E \Pi_{3}<-B . \\
& \left(V_{L}-w\right)+\delta\left[(1-\alpha) \theta_{H}\left(V_{H}-w\right)-\left[\alpha+(1-\alpha)\left\{\delta \theta_{H}+\theta_{L}\right\}\right] B\right]<-B . \\
& \left(V_{L}-w\right)+\delta(1-\alpha) \theta_{H}\left(V_{H}-w\right)<-B+\delta\left[\alpha+(1-\alpha)\left\{\delta \theta_{H}+\theta_{L}\right\}\right] B .
\end{aligned}
$$

so that

$$
F C_{2}(B)=B-\delta\left[\alpha+(1-\alpha)\left\{\delta \theta_{H}+\theta_{L}\right\}\right] B .
$$

The left hand side of the inequality in (27) remains unchanged-the low demand state net productivity plus the discounted expected value of a better demand state in period 3 .

Note EQ28: The right hand side, the layoff penalty in the second period, is again zero if the firm discount factor is one, or if benefits are increased by the firm's interest rate between periods.

With layoffs in the low productivity state in the second period, expected profits entering period 2 are:

$$
\begin{aligned}
E \Pi_{2}= & \alpha(-B)+(1-\alpha)\left[\theta_{H}\left\{\left(V_{H}-w\right)+\delta E \Pi_{3}\right\}+\theta_{L}(-B)\right] \\
= & {\left[(1-\alpha) \theta_{H}+\delta\left\{(1-\alpha) \theta_{H}\right\}^{2}\left(V_{H}-w\right)\right.} \\
& \quad-\left[\alpha+\delta\left\{(1-\alpha) \theta_{H}\left\{\alpha+(1-\alpha)\left(\delta \theta_{H}+\theta_{L}\right)\right\}+(1-\alpha) \theta_{L}\right] B .\right.
\end{aligned}
$$




\section{Period 1 (The Hiring Period)}

At the time of hire, the worker presumably has non-negative expected value to the firm:

$$
E \Pi_{1}=\left(\mathrm{V}_{\mathrm{H}}-\mathrm{w}\right)+\delta E \Pi_{2}-\mathrm{h}_{0} \geq 0 .
$$

In this case of no layoff avoidance, the expected value over the contract life to the firm is:

$$
\begin{aligned}
E \Pi_{1}= & {\left[1+\delta(1-\alpha) \theta_{\mathrm{H}}+\left\{\delta(1-\alpha) \theta_{\mathrm{H}}\right\}^{2}\right]\left(\mathrm{V}_{\mathrm{H}}-\mathrm{w}\right) } \\
& -\delta\left[\alpha+\delta(1-\alpha) \theta_{\mathrm{H}}\left\{\alpha+(1-\alpha)\left(\delta \theta_{\mathrm{H}}+\theta_{\mathrm{L}}\right)\right\}+(1-\alpha) \theta_{\mathrm{L}}\right] \mathrm{B}-\mathrm{h}_{0} \\
E \Pi_{1}= & {\left[1+\delta(1-\alpha) \theta_{\mathrm{H}}+\left\{\delta(1-\alpha) \theta_{\mathrm{H}}\right\}^{2}\right]\left(\mathrm{V}_{\mathrm{H}}-\mathrm{w}\right)-\mathrm{h}(\mathrm{B})-\mathrm{h}_{0} }
\end{aligned}
$$

where

$$
h(B)=\delta\left[\alpha+\delta(1-\alpha) \theta_{\mathrm{H}}\left\{\alpha+(1-\alpha)\left(\delta \theta_{\mathrm{H}}+\theta_{\mathrm{L}}\right)\right\}+(1-\alpha) \theta_{\mathrm{L}}\right] \mathrm{B}
$$

Note EQ31: If $\delta=1$ (or benefits are interest rate adjusted between periods), then $h(B)=B$, the mandate insures the worker will receive the severance benefit some day.

Summarizing:

Proposition 5: The substitution of a severance savings plan for a severance insurance plan will reduce firing costs and eliminate them if payments are appropriately adjusted for time of payment, but will increase hiring costs.

The "competitive wage" at zero expected profit, would simply reflect the payout:

$$
\widetilde{W}=V_{H}-\frac{h_{0}+h(B)}{1+\delta(1-\alpha) \theta_{\mathrm{H}}+\left\{\delta(1-\alpha) \theta_{\mathrm{H}}\right\}^{2}}
$$

\section{The Firing Cost/Hiring Cost Interface}

Severance-induced firing costs and hiring costs are quite distinct, and depend in different ways on characteristics of the labor market. The connections are not always transparent. Consider for example the firing cost and hiring cost measures in the mandate model in which the firm does not engage in first order (layoff) avoidance: ${ }^{21}$

$$
\begin{aligned}
& F C_{2}(B)=B-\delta(1-\alpha) \theta_{L} B=\left\{1-\delta(1-\alpha) \theta_{L}\right\} B \\
& h(B)=\left[\delta(1-\alpha) \theta_{\mathrm{L}}+\{\delta(1-\alpha)\}^{2} \theta_{\mathrm{H}} \theta_{\mathrm{L}}\right] \mathrm{B}
\end{aligned}
$$

Mandated severance benefits, of course, have the same qualitative effects on firing costs and hiring costs-higher benefits increase firing costs and gross hiring costs. Other parametric shifts often move the two measures in opposite directions. Indeed contract

\footnotetext{
${ }^{21}$ The same qualitative pattern of effects holds in the model with layoff avoidance, Equations (18) and
} (21). 
avoidance behaviors such as the conversion of a severance insurance mandate to a severance savings plan offers the firm a tradeoff between the two types of costs.

Table 1 summarizes the comparative statics of various parametric changes to firing costs and hiring costs. The impact of a severance mandate varies with the economic environment. For example, an increase in the attrition or quit rate $(\alpha)$ has an intuitive, negative effect on expected gross hiring costs. Because voluntary departures are not covered in severance insurance mandates, an increase in quit rates reduces expected expenditures. The effect on firing costs is perhaps less intuitive. The firm's net cost of a layoff depends not only on the current expenditure that it is required to make, but also on changes in its future liabilities. An increase in (uncovered) quit rates decreases the likelihood the worker will receive severance benefits in the future, which in turn makes the expected cost of a current layoff greater.

Similarly the impact of a higher likelihood of a low demand state $\left(\theta_{L}\right)$ increases hiring costs and decreases firing costs. The impact on hiring costs is straightforward. Realization of the low demand state is the insured event, and increasing its likelihood will increase expected payouts from the insurance plan. At the time of potential release, however, firing costs are less because the firm appreciates that it has a greater probability of paying out benefits in future periods if it does not lay off the worker today. In the extreme, the firm "knows" it will be paying out severance at some point and, discounting issues aside, has no reason to delay the inevitable payout. This can happen in severance insurance plans as well as severance savings plans if the probability of covered (involuntary) separations approach one. ${ }^{22}$ As the payout probability grows, the severance insurance plan approaches a severance savings plan.

The discount factor, one over the sum of one plus the discount rate), offers a slightly different story, but only slightly. A higher discount factor $(\delta)$ means the firm values the future more completely. The severance-induced hiring cost measure increases as a consequence, because hiring takes place in the present, and negative demand draws (and related benefit

22 See Parsons (2011a) for examples. 
payouts) in the future. Firing costs will decrease, however. The benefit expenditure is in the present and undiscounted. Future severance liabilities, which will be reduced with a payout today, are discounted and will be less in expectation. The effect is to reduce net firing costs.

To give a better sense of the potential magnitudes of these effects and their complexity, consider the following simulation of second period firing costs and (first period) hiring costs. Assume a base structure for this three-period employment model in which the government would like to insure that the worker receives a severance benefit of $B=100$ whenever she is forced to leave the job. This could be achieved by mandating the obvious severance insurance plan or a severance savings plan which pays out $B=100$ whenever the worker leaves the firm and for whatever reason--involuntary, voluntary, or retirement. There would still be nonzero firing cost effects with severance savings if the discount factor is less than one, reflecting the fact that the firm has some incentive to delay payout, but would be zero if the discount factor is one (payouts are interest adjusted). The hiring costs effect would be the discounted likelihood of separation in each of the three work periods and would simply equal 100 if the firm's discount factor is 1.

To fill out the parameters of the base model, assume that $\delta=0.7, \alpha=0.3, \theta_{L}=\theta_{H}=$ 0.5 and again $B=100$. In the severance insurance plan in this base case, firing costs are now 75.5 and severance induced hiring costs are 30.5. Under the savings plan in the base environment, second period firing costs are 37.35 and severance-induced hiring costs are 60.9. Firing costs are not zero when the discount factor is 0.7 and benefits are fixed across periods, because the firm gains significantly by postponing benefit payout.

Returning to the severance insurance plan, outcomes respond dramatically to variations in the underlying parameters, Table 2. For example, increasing natural attrition ( $\alpha$ ) from 0.0 to 1.0 , while holding other parameters constant, increases firing costs from 65 to 100 while decreasing hiring costs from 47.2 to 0.0 . Again, if the worker will exit with certainty in the next period without incurring severance benefit eligibility, the employer "saves" the 
entire benefit payout by retaining the worker in this period, dramatically increasing firing costs.

Varying the probability of a low demand period $\left(\theta_{\mathrm{L}}\right)$ from 0.0 to 1.0 has the opposite effect. Firing costs approach 100 as the prospects of a bad draw in the next period approach zero, and fall by one half (to 51) if the prospects of a bad demand draw in the next period are one. Even if the probability of a bad draw in the next period is zero, the employer may avoid payout because of natural attrition (and the discount rate in nonzero). Conversely hiring costs increase with the likelihood of a low demand state, because payout prospects increase.

The discount factor $(\delta)$ operates on firing costs and hiring costs much like low demand probability $\left(\theta_{L}\right)$, increasing hiring cost as future severance benefits are less severely discounted. Firing costs decrease as the discount factor increases because the "returns" to postponement of a layoff fall as the discount factor rises.

\section{Service-based Severance Mandates}

Mandated severance benefits typically vary with years of service or tenure, often as a simple multiple. In a comprehensive study of national mandates of job separation benefits, Holzmann, Pouget, Weber, and Vodopivec (2011) reported on the benefit payouts at 9 months, 4 years, and 20 years. Of eighty countries with valid entries at four years and twenty years, only 14 (17.5 percent), primarily successor states to the Soviet Union, mandated flat benefits. The ratio of benefits at twenty years to those at four years ranged from one (the 14 states just mentioned) to ten (Albania, Ecuador, and Malawi), Figure 1. The modal ratio of benefits at twenty years to those at four was a factor of five, implying that benefits increase in proportion to service. A total of 26 countries (32.5 percent of the sample) reported exactly this figure, with several others quite close.

Although voluntary severance plans in the U.S. are more varied, almost all have some element of benefits increasing in proportion to service, Parsons (2005). Especially for blue collar and service workers and clerical workers, the modal plan offers one week of pay 
per year of service, Parsons (2005). Among upper level administrators, two weeks per year of service is common. Only among senior executives are individually negotiated contracts the norm.

Pagés and Montenegro (2007) raised a potentially important policy concern with service-linked severance mandates--that younger workers would be disadvantaged, the first on the firm's layoff queue, because of the higher firing costs associated with older, longerservice workers. ${ }^{23}$ The present model, suitably modified, lets us explore this issue, although it, like the related model of Pagés and Montenegro (2007), is not ideal for analyzing this question because there is no possibility of substitution between members of different employment cohorts. Taken literally, the model can only be used to assess whether the range of parameters over which layoffs will occur is larger or smaller for the various cohorts. If the range of layoff parameters is made smaller by a policy for one employment cohort than another, we will say that that cohort is favored by the policy.

If one wishes to design severance pay policies that are neutral across generational cohorts, one has to specify the objective more precisely. Two distinct alternatives are:

(i) make policies neutral across the cohorts, or

(ii) more ambitiously, equate layoff incentives across the cohorts.

As noted above, the young in this model are "naturally" favored in the second period, because retained second period (young) workers may be profitable to the firm in the next period should demand recover, a possibility denied older workers in their terminal period in the labor market. Either objective can be achieved, though not with flat rate plans.

First consider the flat severance benefit regime developed to this point. To highlight the role of benefits, assume that layoff avoidance is absent. Firing costs for the two cohorts then are:

$$
\begin{array}{ll}
\text { Period } 3 \text { Cohort: } & F C_{3}(B)=B . \\
\text { Period } 2 \text { Cohort: } & F C_{2}(B)=B-\delta(1-\alpha) \theta_{L} B .
\end{array}
$$

\footnotetext{
${ }^{23}$ Labor union contracts often mandate first-in first-out layoff policies independent of price incentives, no doubt partly the consequence of the greater voting power of senior workers.
} 
Firing costs in the second period are systematically less because a layoff in period 2 releases the firm from paying the worker benefits in period 3, which the firm can expect with positive probability. It is transparent that flat rate benefit scheme cannot secure equal benefit-linked firing costs across hiring cohorts because the coefficient on benefits on the RHS of (10) is everywhere smaller in magnitude than that in (8).

Proposition 6: A flat rate severance benefit scheme cannot be policy neutral across cohorts. The period 2 cohort will have lower firing costs at any level of $B$.

A flat rate system can however be used to equalize the layoff likelihood in total. Although firing costs are smaller for the Period 2 cohort, expected operating losses from retaining a member of the Period 2 cohort is also less. Consider the layoff algorithm for the two cohorts in a low demand state:

$$
\begin{array}{ll}
\text { Period } 3 \text { Cohort: } & V_{L}-w<-B . \\
\text { Period } 2 \text { Cohort: } & \left(V_{L}-w\right)+\delta(1-\alpha) \theta_{H}\left(V_{H}-w\right)<-\left\{1-\delta(1-\alpha) \theta_{L}\right\} B .(10)
\end{array}
$$

One need only increase benefits to the point that they offset the natural advantage of the younger cohort:

$$
B=\frac{\theta_{H}}{\theta_{L}}\left(V_{H}-w\right)
$$

The more obvious policy target is to neutralize the severance mandate effect only, and to do that it is necessary to vary benefits with service. The layoff decision rules for the two cohorts when the severance benefit varies across cohorts are:

$$
\begin{array}{ll}
\text { Period } 3 \text { Cohort: } & V_{L}-w<-B_{3} \\
\text { Period } 2 \text { Cohort: } & \left(V_{L}-w\right)+\delta(1-\alpha) \theta_{H}\left(V_{H}-w\right)<-B_{2}+\delta(1-\alpha) \theta_{L} B_{3}
\end{array}
$$

and the corresponding firing cost vectors $\left(B_{2}, B_{3}\right)$ :

$$
\begin{array}{ll}
\text { Period } 3 \text { Cohort: } & F C_{3}\left(B_{2} \cdot B_{3}\right)=B_{3} . \\
\text { Period } 2 \text { Cohort: } & F C_{2}\left(B_{2} \cdot B_{3}\right)=B_{2}-\delta(1-\alpha) \theta_{L} B_{3} .
\end{array}
$$

Clearly it is now possible to adjust benefits in such a way that the impact of the mandate on firing costs would be neutral across cohorts. It Is only necessary that:

$$
B_{2}=\left\{1+\delta(1-\alpha) \theta_{L}\right\} B_{3} .
$$


Because the coefficient on $B_{3}$ is greater than one, it must be that the firing-cost-neutral benefit structure requires that $B_{2}$ exceed $B_{3}$-severance benefits should decrease in generosity with seniority.

Proposition 7 A firing cost neutral severance insurance plan requires that benefits decrease with the worker's service with the firm.

It is simple to move beyond making the mandate policy-neutral, and design a benefit structure that equates layoff prospects between cohorts, essentially offsetting the natural advantages of youth in this model. Increasing third period benefits $\left(B_{3}\right)$ will discourage third period layoffs while making second period layoffs more likely, and it is transparent that a sufficiently large severance mandate in period $3\left(B_{3}\right)$ will have the firm laying off younger workers more freely than older workers.

Indeed one can imagine a benefit schedule with benefits for the third period cohort so high that firms would systematically lay off all workers in the second period independent of demand state, to avoid accruing the additional severance liability. ${ }^{24}$ The mandate schedule might induce the firm to operate with short-service workers despite underlying incentives, in this case recruiting costs, to operate with long-service workers. The popularity of temporary contract workers in some severance-mandating countries suggests that firms do make such calculations, OECD (2004).

In all these calculations, however, one must recognize the upper bound on severance benefit effects. The discussion has focused on the range of benefits that would not induce layoff avoidance. Once benefits induce the firm to retain workers in the low demand state, additional benefit increments have no effect on firm behavior.

\section{Conclusion}

Substantial severance (insurance) benefits would seem like a serious impediment to the efficient release of workers in low demand periods and even to new hires in high demand periods, and it is natural to ask why the empirical record provides no evidence of either. A

${ }^{24}$ Prior to ERISA, when cliff-vesting was common, for example pensions vesting only with thirty years of service, the claim was often made that firms strategically released workers at 29 years of service. For a review of the pre-ERISA world of pensions, see Thompson (2005). 
three period employment model is used to derive formal measures of firing costs and hiring costs to explore this issue. These are employed to clarify the impact of mandated severance plans on major employment decisions. The model reveals that firing costs are generally less than severance benefit levels, and perhaps sharply less. The linkage between severance benefit generosity and "firing costs" depends on a variety of factors, including voluntary separation rates and the likelihood of future (covered) involuntary separations, most of which dampen any labor market response.

Moreover firing costs do not translate in any simple way into hiring costs and therefore new hires. Severance insurance benefits may be large but rarely paid out, if, for example, most hires reach normal retirement with the firm; hiring costs are correspondingly low. Conversely firing costs would be high in this case, approaching severance benefit levels. Contractual avoidance of firing cost effects by converting a severance insurance plan into a severance savings plan reduces firing costs even as it increases gross hiring costs.

The bulk of the paper employs a fixed benefit mandate, but extends simply to a more realistic service or tenure linked benefit structure. The broader model is used to confront a policy concern raised by Pagés and Montenegro (2007)--that severance mandates increasing in service may induce firms to layoff younger workers disproportionately. The model permits design of a cohort-neutral severance mandate of unexpected structure. 


\section{REFERENCES}

Azariadis, Costas. 1975. "Implicit Contracts and Underemployment Equilibria," Journal of Political Economy, 83 (December), 1183-1202.

Baily, Martin Neil; 1974 "Wages and Employment under Uncertain Demand," Review of Economic Studies, v.41.1 (January): 37-50.

Bentolila, Samuel and Giuseppe Bertola. 1990. "Firing Costs and Labor Demand: How Bad is Eurosclerosis?" Review of Economic Studies 57.3(July): 381-402.

Bertola, Giuseppe. 1990. "Job Security, Employment, and Wages." European Economic Review 34 (1990): 851-886.

Bertola, Giuseppe. 1992. "Labor Turnover Costs and Average Labor Demand." Journal of Labor Economics" 10(October): 389-411.

Bertola, Giuseppe. 1999. "Microeconomic Perspectives on Aggregate Labor Markets." Labor Turnover Costs and Average Labor Demand." in Orley Ashenfelter and David Card, eds. Handbook of Labor Economics Vol 3C Amsterdam: Elsevier 2985-3028.

Bishow, John, and Donald O. Parsons. 2004. "Trends in Severance Pay Coverage in the United States. 1980-2001" (May) Available at SSRN:

http://ssrn.com/abstract=878144

Blackwell, David W.; M. Wayne Marr, and Michael F. Spivey. 1990. "Plant-Closing Decisions and the Market Value of the Firm Source," Journal of Financial Economics v26.2 (August): 277-88.

Blanchard, Olivier. 1998. "Employment Protection and Unemployment." mimeo.

Blanchard, Olivier. 2006. "European Unemployment: The Evolution of Facts and Ideas," Economic Policy (January) 5-59.

Blau, Francine, and Lawrence M. Kahn. 1999. "Institutions and Laws in the Labor Market," in Orley Ashenfelter and David Card, eds. Handbook of Labor Economics, Vol. 3 13991461.

Boeri, Tito, and Pietro Garibaldi. 2009. "Beyond Eurosclerosis," Economic Policy (July): 409461.

Boeri, Tito, Brooke Helppie, and Mario Macis. 2008. "Labor Regulations in Developing Countries: A Review of the Evidence and Directions for Future Research," Social Protection and Labor: The World Bank, SP Discussion Paper No.0833 October.

Buechtemann, C.F. 1992. ed. Employment Security and Labor Market Behavior: Interdisciplinary Approaches and International Evidence, Ithaca, NY: ILR press, Cornell University.

Clinebell, Sharon K; and John M. Clinebell. 1994. "The Effect of Advance Notice of Plant Closings on Firm Value, Journal of Management; v.20.3 (Fall): 553-565.

Emerson, Michael. 1988. "Regulation or Deregulation of the Labour Market; Policy Regimes for the Recruitment and Dismissal of Employees in the Industrialized Countries," European Economic Review 32 (1988): 775-817.

Feldstein, Martin, and Daniel Altman, 2007. "Unemployment Insurance Savings Accounts" in Tax Policy and the Economy, James Poterba, ed., Vol. 21: 35-63.

Ferrer, Ana M. and W. Craig Riddell. 2011. "Unemployment Insurance Savings Accounts in Latin America: Overview and Assessment." In Robert Holzmann and Milan Vodopivec, eds., Improving Termination Pay: An International Perspective, Washington, DC: World Bank. 
Garibaldi, Pietro, and Lia Pacelli. 2003. "Mandatory Severance Payments in Italy: Do They Exist?" paper presented at the World Bank/IIASA/Ludwig Boltzmann Institute International Workshop on Severance Pay Reform: Toward Unemployment Savings and Retirement Accounts, Laxenberg/Vienna, November 7-8.

Gavin, Michael.K. 1986. "Labor Market Rigidities and Unemployment: The case of Severance Costs," Federal Reserve International Finance Discussion Papers, No, 284. http://www.federalreserve.gov/pubs/ifdp/1986/284/ifdp284.pdf

Gombola, Michael J.; and George P. Tsetsekos. 1992. "The Information Content of Plant Closing Announcements: Evidence from Financial Profiles and the Stock Price Reaction," Financial Management v21.2 (Summer 1992): 31-40.

Heckman, James J., and Carmen Pagés. 2004. "Introduction," in Heckman and Pagés, eds., Law and Employment: Lessons from Latin America and the Caribbean, Chicago, The University of Chicago 1-107.

Holzmann, Robert, Yann Pouget, Michael Weber, and Milan Vodopivec. 2011. "Severance Pay Programs around the World: History, Rationale, Status, and Reforms" In Robert Holzmann and Milan Vodopivec, eds., Improving Termination Pay: An International Perspective, Washington, DC: World Bank (forthcoming).

Lazear, Edward P. 1990. "Job Security Provisions and Employment," Quarterly Journal of Economics 105 (August: 699-726.

Malcomson, J. 1999. "Individual Employment Contracts," in Orley Ashenfelter and David Card, eds. Handbook of Labor Economics, Vol. IIIB, Chapter 35, North Holland Press pp.2291-2372.

Nickell, Stephen, J. 1978. "Employment and Labour Demand over the Cycle," Economica, New Series, vol. 45, No. 180 (November): 329-345.

OECD. 1999. "Employment Protection and Labour Market Performance," in OECD Employment Outlook, Chapter 2, Paris: OECD.

OECD. 2004. "Employment Protection Regulation and Labour Market Performance," in OECD Employment Outlook, Chapter 2, Paris: OECD.

OECD. 2006. "Reassessing the Role of Policies and Institutions for Labour Market Performance: A Quantitative Analysis," in OECD Employment Outlook, Chapter 7, Paris: OECD.

Pagés, Carmen, and Claudio E. Montenegro. 2007. "Job Security and the Age-Composition of Employment: Evidence from Chile." Estudios de Economia vol.34 iss.2: 109-139.

Parsons, Donald O. 1977. "Models of Labor Turnover: A Theoretical and Empirical Survey" in Research in Labor Economics, Ronald Ehrenberg, ed., 185-224.

Parsons, Donald O. 1986. "The Employment Relationship: Job Attachment, Work Effort, and the Nature of Contracts" in Orley Ashenfelter and Richard Layard, eds. Handbook of Labor Economics, Vol. II, North Holland Press: 789-848.

Parsons, Donald O. 2005. "Benefit Generosity in Voluntary Severance Plans: The U.S. Experience" Available at SSRN: http://ssrn.com/abstract=877903. 2005c.

Parsons Parsons, Donald O. 2011a. "The Firing Cost Implications of Alternative Severance Pay Designs" In Robert Holzmann and Milan Vodopivec, eds., Improving Termination Pay: An International Perspective, Washington, DC: World Bank. (Available as IZA DP. 4967.)

Parsons, Donald O. 2011b. "Mandated Severance Pay and Firing Cost Distortions: A Critical Review of the Evidence," In Robert Holzmann and Milan Vodopivec, eds., Improving 
Termination Pay: An International Perspective, Washington, DC: World Bank. (Available as IZA DP. 5776.)

Parsons, Donald O., 2011c "Double-Sided Moral Hazard In Job Displacement Insurance Contracts," mimeo, George Washington University.

Rosen, Sherwin. 1985. "Implicit Contracts: A Survey," Journal of Economic Literature 23 (September): 1144-1175.

Salanié, Bernard. 2005. The Economics of Contracts: A Primer, Second Edition, MIT Press.

Thompson, John W., 2005. "Defined Benefit Plans at the Dawn of ERISA." U.S. Bureau of Labor Statistics, Compensation and Working Conditions Online, Originally Posted: March 30.

Topel, Robert. 1990. "Financing Unemployment Insurance: History, Incentives, and Reform" in Unemployment Insurance: The Second Half-Century, edited by W. Lee Hansen and James F. Byers. Madison, WI: the University of Wisconsin Press: 107-172.

Vodopivec, Milan. 2004. Income Support Systems for the Unemployed: Issues and Options, World Bank: Washington, DC. 
TABLE 1

COMPARATIVE STATICS OF SEVERANCE-INDUCED FIRING AND HIRING COSTS

\begin{tabular}{|l|c|c|}
\hline & Firing Costs & Gross Hiring Costs \\
\hline & & \\
\hline Severance Benefits $(\mathrm{B})$ & + & + \\
\hline Attrition (Quit) Rate $(\alpha)$ & + & - \\
\hline Probability of Low Demand State $\left(\theta_{\mathrm{L}}\right)$ & - & + \\
\hline Firm Discount Factor $(\delta)$ & - & + \\
\hline
\end{tabular}


TABLE 2

FIRING COST AND HIRING COST SIMULATIONS

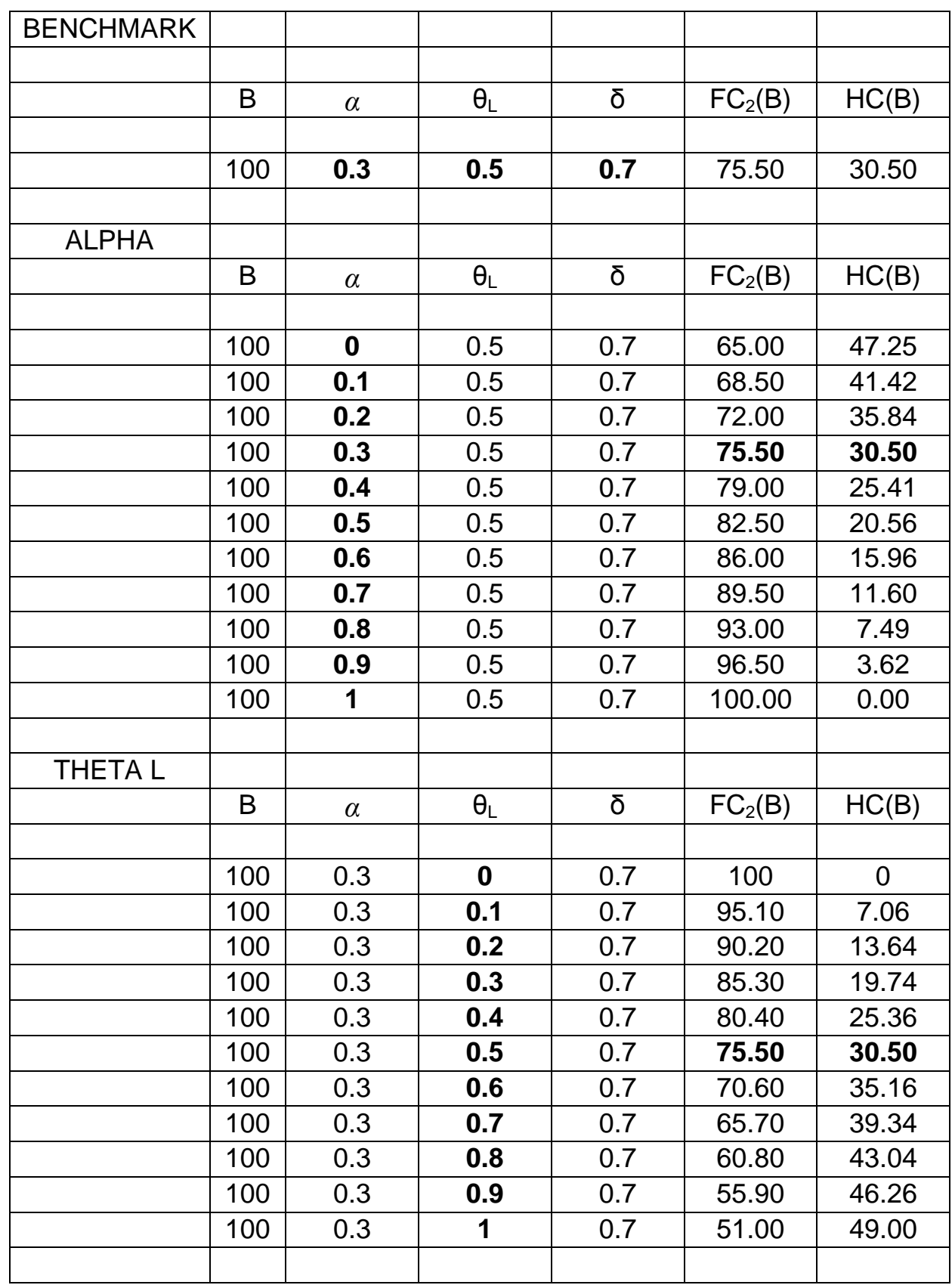


TABLE 2 (CONTINUED)

\begin{tabular}{|c|c|c|c|c|c|c|}
\hline DELTA & & & & & & \\
\hline & $\mathrm{B}$ & $\alpha$ & $\theta_{\mathrm{L}}$ & $\delta$ & $\mathrm{FC}_{2}(\mathrm{~B})$ & $\mathrm{HC}(\mathrm{B})$ \\
\hline & & & & & & \\
\hline & 100 & 0.3 & 0.5 & $\mathbf{0}$ & 100.00 & 0.00 \\
\hline & 100 & 0.3 & 0.5 & $\mathbf{0 . 1}$ & 96.50 & 3.62 \\
\hline & 100 & 0.3 & 0.5 & $\mathbf{0 . 2}$ & 93.00 & 7.49 \\
\hline & 100 & 0.3 & 0.5 & $\mathbf{0 . 3}$ & 89.50 & 11.60 \\
\hline & 100 & 0.3 & 0.5 & $\mathbf{0 . 4}$ & 86.00 & 15.96 \\
\hline & 100 & 0.3 & 0.5 & $\mathbf{0 . 5}$ & 82.50 & 20.56 \\
\hline & 100 & 0.3 & 0.5 & $\mathbf{0 . 6}$ & 79.00 & 25.41 \\
\hline & 100 & 0.3 & 0.5 & $\mathbf{0 . 7}$ & $\mathbf{7 5 . 5 0}$ & $\mathbf{3 0 . 5 0}$ \\
\hline & 100 & 0.3 & 0.5 & $\mathbf{0 . 8}$ & 72.00 & 35.84 \\
\hline & 100 & 0.3 & 0.5 & $\mathbf{0 . 9}$ & 68.50 & 41.42 \\
\hline & 100 & 0.3 & 0.5 & $\mathbf{1}$ & 65.00 & 47.25 \\
\hline
\end{tabular}




\section{FIGURE 1}

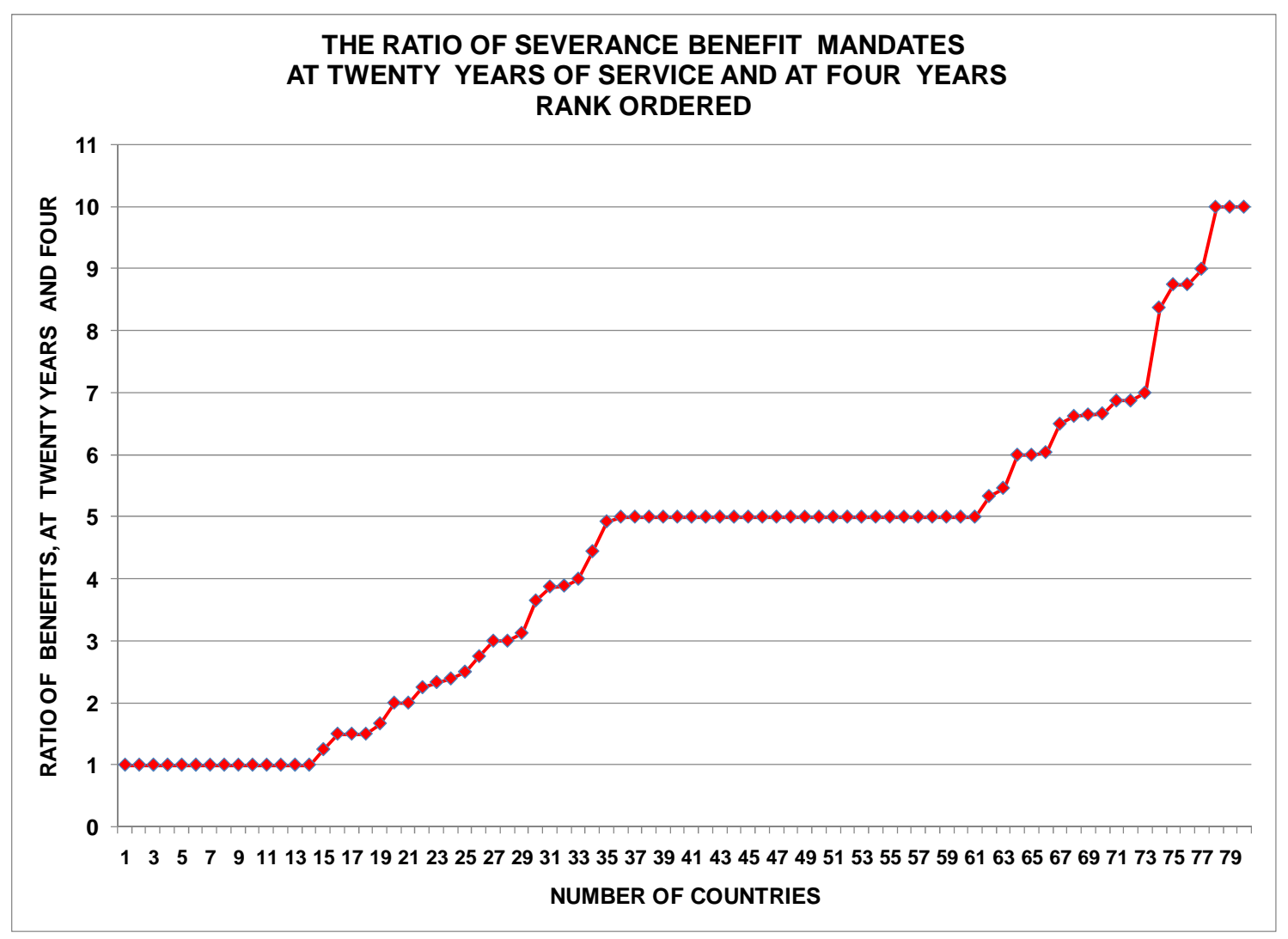

Source: Holzmann, Pouget, Weber, and Vodopivec (2011). 